\title{
Analysis on the Teaching Reform of Ideological and Political Course under the Network Background
}

\author{
Jun $\mathrm{Li}^{1, \mathrm{a}^{*}}$ \\ ${ }^{1}$ Shaanxi University of Chinese Medicine, Xianyang, Shaanxi 712046, China \\ abaojilijunjun@163.com \\ * The Corresponding Author
}

Keywords: Networking; Ideological and Political Theory Courses; Reform, Coping Strategies

\begin{abstract}
With the advent of the Internet age, information technology has penetrated into many fields such as politics, economy, and culture. Humankind's production methods, lifestyles, and learning methods have undergone major changes. The ideological and political work under the background of the Internet age is bound to be challenged and impacted by the new characteristics of the Internet era. The classroom teaching of ideological and political courses in colleges and universities is the core link and main channel of ideological and political education in universities. In this context, the ideological and political theory class urgently needs a new teaching model to make up for the shortcomings of the traditional teaching model. This article discusses the necessity of the networked reform of the ideological and political theory course, the basic principles of the reform, the challenges faced, and the countermeasures.
\end{abstract}

\section{The Necessity of Networking Reform of Ideological and Political Theory Courses}

The characteristics of the ideological and political theory courses in colleges and universities and their objectives and tasks are the focus of networked reforms The ideological and political theory courses in colleges and universities not only teach students theoretical knowledge, but also develop students' perspectives on problem solving and problem solving, and establish correctness. The position. As the main channel and main position of ideological and political education for college students, it is different from general intellectual education and cultural knowledge classes. It must understand the curriculum and teaching activities from the perspective of politics, strategic height, and direction. Its goal is to understand the national conditions, the world conditions, and the party's situation. On the basis of education on the history of the country, guide students to conscientiously understand the laws of development of Chinese society since modern times, hold high the banner of Marxism and follow the modernization road of socialism with Chinese characteristics. Focusing on students' hot pots, difficulties, and doubts, the theory is linked to reality, combining the theoretical learning of classroom teaching with the social exercises in practice, and constantly raising students'awareness of practice, focusing on practice, understanding practice, participating in practice, In the process of interpreting reality and transforming the subjective and objective world, we will improve ideological and moral qualities and scientific and cultural qualities, thereby highlighting the scientific nature, explanatory power, and acting power of the theory. The nature, objectives, and tasks of the course inevitably require that students not be able to memorize concepts, ideas, and principles of the old methods, but must be close to the students' way of thinking, learning methods and lifestyle, through reform and innovation to get close to students, to attract students.

In traditional teaching, although students can also carry out some extra-curricular learning based on interests and conditions, they are still passive in various aspects such as study time, learning progress, learning content, and learning methods. In the age of the Internet, college students became accustomed to choosing appropriate learning resources according to their own time schedules and learning in accordance with their own methods, including attending classes, answering questions after class, discussing, practicing tests, browsing related extracurricular resources, and taking notes. Therefore, the ideological and political theory courses in colleges and universities must adapt to the new changes in the way of thinking and learning of the university students, extend the "talents" and 
face the Internet. Compared with the traditional curriculum, this brand-new education model mainly using computer, network, multimedia and other technical means has the characteristics of large number of resources, rapid update, multiple sources, wide range, and more convenient acquisition methods. Online courses that have been commonly used in colleges and universities are reference points for network reform. Accompanying information and communication technologies, especially the continuous development of network technologies, online courses have become a new form of university classrooms. Overcoming the limitations of human resources, material resources, and funds, it has extended the classroom, overcoming the inadequacies of organizing teaching by classes, teaching by teachers, and passive acceptance by students, enabling interactive learning and effectively avoiding loneliness in learning. To sum up, as a change in traditional education methods to meet the needs of China's high-quality personnel training, the online curriculum that is in the ascendant in the world is integrated with knowledge, interest, visuality, and intuition, achieving far better results than ordinary classroom teaching. As an organic part of college curriculum, ideological and political theory courses naturally cannot be isolated from the mainstream of this teaching reform.

\section{The Basic Principles of the Networked Reform of Ideological and Political Theory Courses in Colleges}

The reform and innovation of the ideological and political theory courses in the new era must truly establish a student-centered philosophy, provide optimal services for student growth and success, and must correct the past from the perspective of teacher work and use students as a test. The object is to explore the biased ideas and practices of teachers' teaching methods. The student-centered approach should be reflected in all aspects and the whole process of the reform of ideological and political theory courses in colleges and universities. To be student-oriented, you must understand students and understand students, have a deep understanding of the students' strengths and weaknesses, and have a better understanding of students' learning status and growth needs. And as a benchmark to improve teaching methods, application of educational technology, pay attention to teaching arts, enrich teaching content, increase the total amount of knowledge, and enhance scientific research content. To be student-oriented, network-based reforms must focus on serving students and serve the students wholeheartedly. In the teaching process, we must take the teaching content into the student's mind as the fundamental starting point and end result. With the goal of stimulating students' interest and mobilizing their internal learning motives in teaching activities, they should be accepted and welcomed by students in the teaching method as the evaluation scale to improve students. The learning strategies and learning abilities provide the best services for the growth of students and make them truly high-quality courses that are "loved and benefited for life" for contemporary college students.

The networked reform should promote teachers' level promotion and self-worth realization. As one of the teachers of modern education, it is naturally an important object of the people-oriented principle of networked reform. In the reform, the interests of teachers must be taken into consideration. Teachers should identify, support, participate in, and promote teaching reform activities with self-development and self-worth. However, it cannot be said that reforms are not related to them or contribute little to development and are ignored. It even hinders the advancement of reforms. The new requirement of teachers for online teaching is a new driving force for teacher self-development. In traditional teaching, teachers are the absolute authority in teaching and are the owner and disseminator of knowledge. In online teaching, teachers will be transformed into guides and helpers for student learning and supporters of student knowledge construction. This requires teachers to look at the world trend according to the new situation, grasp the pulse of the times, constantly summarize new experiences, optimize teaching concepts, enrich teaching content, and improve teaching methods and teaching methods. Not only do they become users and operators of teaching software or teaching resources. It should become a designer, creator, and researcher of teaching resources. While improving information awareness, information capabilities, and information ethics, they can also be freed from the tedious and repetitive mechanical classroom 
lectures, have more time and energy to engage in scientific research, improve academic standards, and promote professional titles. The improvement of social status better realizes self-worth.

The principle of integrity must be firmly reflected in the integrity of the networked reform of college ideological and political theory courses means that it is full participation, not a sporadic spontaneous reform of one or more teachers. First, the networked reform is the reform of all the contents of all the courses that are attended by all the staff. If only a certain knowledge point, a chapter, or a course is reformed, it will inevitably fragment the interrelationships between knowledge points and the internal links of theory, affect the integrity and logical persuasiveness of the theory itself, and weaken the ideological and political theory. Consistency and mutual support between classes. Second, networked reform is not only an alternative to teaching methods, but also a comprehensive reform and new combination of teaching activities. The networked reform is an organic combination and optimized combination of various teaching methods based on the online teaching method, rather than a simple replacement of either one or the other. It must follow the overall principle. There is no doubt that the lecture method is still the main method of class teaching in ideological and political theory courses, because the abstract theoretical course can only be understood and applied accurately by the students at the level they should have. Third, the networked reform is not only the reform of teaching methods, but also the "combination boxing" of teaching philosophy, teaching methods and teaching management. The networked reform must strive to ensure that all students and all classes in the school can enjoy high-quality teacher resources with relatively high quality and high teaching standards and benefit from it.

\section{Problems in the Teaching of Ideology and Politics in Colleges}

Although ideological and political education is highly valued by the school, many ideological and political education courses for colleges and universities are only supportive of action and economic support. They do not attach importance to ideology and do not encourage ideological and political education. The reform, without thinking about how to carry out ideological and political education in the current context, will be more effective, and will only take ideological and political education as a task. Many classroom teachers and students also believe that ideological and political classes are empty theoretical teaching and learning, lacking practicality. Under the influence of these stereotyped ideas, classroom teachers do not think about how ideological reforms will be carried out. Courses will be boring. Students will only learn to complete credits, they will not have internalized teaching content, and teaching results will be poor.

The Detachment from the Social Reality is Not only a Theoretically Strong Subject, but also a Subject Closely Related to Social Reality. However, most of the current ideological and political education is purely theoretical, and it is seriously out of line with social reality. If teaching can relate to social reality, take the example around to analyze the tremendous achievements of society, analyze the typical "negative information" with students, and guide students to think about what is mainstream and what is non-mainstream through reverse thinking and dialectical analysis. Etc., so that students can understand the great achievements and social realities.

The Ideological and Political Education Curriculum is the Leading Discipline of All Disciplines. The development of any discipline cannot be separated from the correct ideological guidance. In recent decades, major progress in science and technology in China has been achieved with the active guidance and vigorous promotion of the party and the government. Therefore, when teaching other subject knowledge, colleges and universities should first make students understand that the development of the discipline can not be separated from the support and promotion of the party and the country, and the content of the lesson of the political lesson is considered in the discipline, especially when major progress of the discipline. It is even more inseparable from the guidance of the party and the government so that students can recognize and internalize ideological and political content while they are learning professional knowledge.

Students Do not Want to Instill Knowledge, They are Interested in the Analysis of All Kinds of Knowledge. students do not want every class to face the blackboard full of copying notes, they are interested in dynamic, there are Visual effects for multimedia, such as PPT, videos and pictures. 
The single teaching method and method is now an era of information explosion. The traditional teaching methods (learning in class, chalk board books) have failed to attract students' interest. The knowledge students taught by the teacher can be found through the Internet through computers and mobile phones, even The teacher did not complete a lesson and the student had already learned the content through the mobile phone.

The Contents of the Teaching Materials are Lagging behind, and Students Lack Interest. Since the textbooks for ideological and political education in universities are mainly based on theoretical things, they are relatively boring and unsuitable for attracting students' interest. Therefore, the ideological and political education in universities must closely integrate with the requirements of the times. Firstly, the textbook system should be combined with the actual follow-up of the society in time. Secondly, the teaching methods should be a comprehensive application of participatory, case-analysis, and discussion methods, and the students' participation should be emphasized. In the end, we will guide students in applying the ideology lessons to their own purposes and use them in daily life to guide professional learning.

\section{How to Deal With the Reform of Ideological and Political Education Under the Network Background}

Introduce and use Online Language in Teaching Language in a Timely Manner to Enhance the Sense of the Times and Affinity. The widespread use of network language in the daily life of college students has become a basic fact. The network language has the characteristics of personalization, picture sense, and humorousness, and it is in line with the traits of network life virtuality and interactivity. The network terms have specific meanings in their specific contexts, become common language for college students, and are also important for their identity. component. The timely and appropriate introduction of these online discourses by ideological and political teachers will enhance the vividness and intimacy of the language of instruction, and enhance the attractiveness and teaching effects of ideological and political classes in college students' hearts and minds.

Introduce and use Network Hot Words, Expand Topics, and Interpret Teaching Content. Network hot words, or network buzzwords, are the linguistic fashions that arise in the online cultural environment. Many internet hot words are born in the process and influence of some social events and social phenomena. These hot words have certain discussion value. They can become the best material for introducing and expanding topics in class teaching in the ideological and political classroom, and vividly interpreting the content of the teaching. Many internet hot words can be good materials for classroom teaching.

Introduce and Apply Hot Topics on the Internet. The real-time, interactive, and free nature of the network determines that it is the most rapid communication platform for all kinds of domestic and international events and social phenomena, and has the most points of view. It can target different political, economic, cultural and other events and social phenomena at different time periods. Various hot topics of the Internet are quickly generated. This hot and fresh hot topics on the Internet are diverse in values and distinctive in the times. The group of college students has a strong curiosity and desire to explore these hot topics on the Internet. If the related hot topics are properly and critically introduced into the ideological and political education, not only can these hot topics become vivid and lively. Teaching materials can also greatly enhance the pertinence and effectiveness of ideological and political teaching.

Introduce and Criticize the Representative Issues Related to the Network in Various Forums. The Internet has become the main battlefield for information gathering and distribution centers, public opinion, and ideological struggle. Some anti-traditional, non-mainstream, irrational, and even reactionary speeches and ideas on the Internet are also spreading. The group of college students has not fully matured due to its world outlook, values, and outlook on life. Therefore, some so-called opinion leaders of the masses, such as online celebrities, public knowledge, and Internet-based views, are eagerly sought after by many young students, and some radical or even reactionary speeches are also confused. Audiovisual impact on the development of correct ideas and 
viewpoints of college students will directly impact the teaching of ideological and political education in colleges and universities. In the face of these problems, in the teaching of "basic" classes, on the one hand, we must actively introduce representative views of forum opinion leaders that are in line with the mainstream opinions of the society to support the teaching content; on the other hand, we must introduce some obvious problems or The analysis and criticism are based on the so-called publicly known and Big V typical speeches with bad intentions.

The Introduction and Application of Network Original Works. The diversification, lively forms and grassroots qualities of the original works of the Internet determine that if used properly, it will be a treasure house of ideological and political teaching materials. In the long-term "basic" teaching practice, the author has conducted many beneficial attempts in this regard. For example, in the teaching content design of the "Basic" class college life adaptation section, the theme net posts and discussion-style follow-ups on college campus life BBS were introduced and analyzed and explained. These net-posted statements were pointed out. The questions and the merits of the questions were then inserted into the relevant content of the teaching content in a timely manner. These netizens with strong sense of identity were turned into vivid and lively teaching materials that made the content of the teaching materials into the heart. The introduction of online original works into the classroom should not only be timely and appropriate, but also pay attention to the objective evaluation of network works, and the introduction of teaching content on the basis of this, which requires the ideological and political teacher's insight, theoretical basis and material grasping ability.

\section{Conclusion}

The Internet age is a time of real resource sharing. Network resources have greatly enriched students' knowledge. Here, everyone can enjoy all resources on the Internet equally. Both students and teachers can get first-hand materials on some events. As teachers, we should also use the Internet resources to change the content of boring teaching materials, enrich teaching content, and enhance the ideological and political materials of the times. At the same time, networkization has provided new perspectives, new ideas, and new methods for the reform of ideological and political education in universities in the new era, prompting us to continue to explore how to use network technology to innovate new teaching methods for ideological and political education in universities.

\section{References}

[1] Li Yuping, Tao Su. The Challenges and Countermeasures of Ideological and Political Courses in the Network Background [J]. Research on Ideological and Political Work, 2014(8).

[2] Yin Hongmin. A Study on the Reform of Ideological and Political Education in Universities under the Network Background [J]. Knowledge Economy, 2014(18):151-152.

[3] Wang Shoulan. Problems and Countermeasures in the Application of Network Teaching Platform in Ideological and Political Education in Universities [D]. Jiangnan University, 2015.

[4] Ding Wei. Research on the Teaching Reform of Network Teaching Platform and Ideological and Political Education in Colleges and Universities[J]. Computer Affaires, 2017(6):187-188.

[5] Chen Xingdong. Research on the Construction of Network Platform for Ideological and Political Education in Colleges and Universities [J]. Educational Exploration, 2011, 2011(9):100-101. 